\title{
A Study in the Viability of Butea Monosperma Seeds
}

\author{
Anupama Modi ${ }^{*}$, Anand Kandya ${ }^{2}$ \\ 1*Department of Botany, Shri Umiya Kanya Mahavidalay, Indore, India \\ ${ }^{2}$ Department of Botany, Dr. Hari Singh Gour University, Sagar, India \\ *Corresponding Author:dranupamamodi@gmail.com, Tel.09826025168
}

Available online at: www.isroset.org

Received: 10/Nov/2017, Revised: 21/Nov/2017, Accepted: 20/Dec/2017, Published: 31/Dec/2017

\begin{abstract}
Tetrazolium testes are employed to evalute seed viability so as to achieve faster as well as reliable results. The Tetrazolium Test involves the use of 2, 3, 5, triphenyl tetrazolium chloride which in a living cell is reduced by the dehydrogenase enzyme system. This reaction yields a red compound called triphenyl formazan. Since this reaction is enzyme mediated the cell in which it is taking place has to be a liveing cell. Stained areas of a tissue in this test indicate occurrence of live cells and unstained ones the necrotic tissue. Thus, the test is considered very reliable to locate living cells. In evaluation of seed viability occurrence of a definite proportion of necrotic tissue to that of live tissue helps to the seed will germinate or not.
\end{abstract}

Keywords - Tetrazolium, Enzyme, Living, Non-living tissue, germination and staining.

\section{INTRODUCTION}

Seed viability is usually assessed by means of a standard germination test requiring a minimum of 3 weeks. However, germination test is not possible in seeds with under developed embryo, or possessing some dormancy, or hard seed coat, and in the conditions not favourable for germination. In such cases, viability has to be determined by some alternative and more reliable methods, which may be less time consuming as well as can be applied to large seed samples. The advantage of such methods is mostly in case of dormant seed samples where germination does not occur under favourable conditions and sometimes due to lack of knowledge, the seeds may be considered as dead.

\section{MATERIAL \& METHODS - TETRAZOLIUM TEST}

1)Preparation of tetrazolium solutions:

2,3,5 - triphenyl tetrazolium chloride is light yellow, water soluble powder. $1 \%$ aqueous solution of this salt was prepared. To get the $7.0 \mathrm{pH}$, TTC salt was dissolved in a phosphate buffer solution prepared in the following way:

Solution - 1: 9.078g. of $\mathrm{KH}_{2} \mathrm{PO}_{4}$ dissolved in one litre of water.

Solution- 2 : $11.876 \mathrm{~g}$. of $\mathrm{Na}_{2} \mathrm{HPO}_{4} \cdot 2 \mathrm{H}_{2} \mathrm{O}$ dissolved in one litre of water.

$400 \mathrm{ml}$ of solution 1 mixed with $600 \mathrm{ml}$ of solution of gave a buffer of $\mathrm{pH} 7.0 .10 \mathrm{gm}$. of TTC powder was dissolved in $1000 \mathrm{ml}$ of this buffer. From this stock solution, various dilutions were made. The stock solution was stored in an umber coloured glass bottle in dark at room temperature and was used for staining upto 6 weeks.

\section{2) Premoistening of seeds :}

Premostening is necessary to make the seeds soft enough to be decoated. Seeds were made to imbibe water by placing them between moistened filter paper upto 8 hours of Seeds of B. monosperma.

\section{3) Decoating of seeds}

To allow easier penetraion of tetrazolium solution stain into the seeds, seed coat was removed with a forcep and needles.

Seeds were bisected while still on the blotter with one clean sliding cut with a sharp razar blade to expose the main structure of embryo. One half of each seed was immediately transferred from blotter to the staining solution in order to avoid drying.

\section{4) Staining of seeds}

Seeds were kept in water after decoating and later on completely dipped in the solution of TTC of various concentrations at $35^{\circ} \mathrm{C}$ in an oven. The staining period and concentration of tetrazolium solution used for B.monosperma is given in Table-1.

\section{OBSERVATION AND INTERPRETATION}

The results of tetrazolium tests are recorded in tables 1 . Staining patterns with fully stained seeds $(23.75 \%)$ and zero stained $(24.45 \%)$ along with intermediates, occurring at lower frequencies, was observed in the samples of Butea 
monosperma. The tetrazolium compound stains only the live tissue. Dark stained areas indicate the presence of fully live tissue. Partially stained or light patches indicate more of dead tissue. Where the embryo was unstained the seed failed to germinate, so also where the embryo was stained but the rest of the seed was not the seeds were less viable. It was observed, therefore, that for good viability the embryo as well as a major part of the rest of the seed need to have live tissue.

Table-1 Various categories of tetrazolium staning pattern in seeds of B. monosperma with viability classes.

\begin{tabular}{|c|c|c|c|c|}
\hline $\begin{array}{l}\text { S. } \\
\text { No. }\end{array}$ & $\begin{array}{l}\text { Catagory of variously } \\
\text { stained seeds }\end{array}$ & $\begin{array}{l}\text { Freque- } \\
\text { ncy }(\%)\end{array}$ & $\begin{array}{l}\text { Viabili- } \\
\text { ty of } \\
\text { seeds }\end{array}$ & $\begin{array}{l}\text { Staining } \\
\text { Pattern }\end{array}$ \\
\hline 1. & $\begin{array}{l}\text { Embryonal axis and } \\
\text { cotyledons completely } \\
\text { stained }\end{array}$ & 23.75 & + & \\
\hline 2. & $\begin{array}{l}\text { Embryonal axis \& } \\
\text { cotyledon } \\
\text { except a small portion } \\
\text { of } \\
\text { opposites to radined } \\
\text { end. }\end{array}$ & 3.25 & + & \\
\hline 3. & $\begin{array}{l}\text { Embryonal axis and } \\
\text { cotyledons stained } \\
\text { except periphery of } \\
\text { cotyledon }\end{array}$ & 9.50 & + & \\
\hline 4. & $\begin{array}{l}\text { Embryonal axis \& } \\
\text { cotyledons } \\
\text { except radicle tip. }\end{array}$ & 2.00 & + & \\
\hline 5. & $\begin{array}{l}\text { Ebryonal axis and less } \\
\text { than } 50 \% \text { cotyledons } \\
\text { unstained. }\end{array}$ & 19.75 & - & \\
\hline 6. & 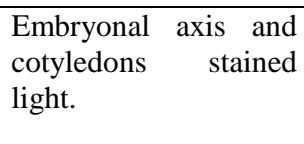 & 11.25 & - & \\
\hline 7. & $\begin{array}{lr}\text { Embryonal } & \text { axis } \\
\text { unstained } & \text { with } \\
\text { cotyledons } & \text { light } \\
\text { stained. } & \end{array}$ & 6.00 & - & \\
\hline 8. & $\begin{array}{l}\text { Embryonal axis and } \\
\text { cotyledons unstained }\end{array}$ & 24.5 & - & \\
\hline
\end{tabular}



Fig : 2

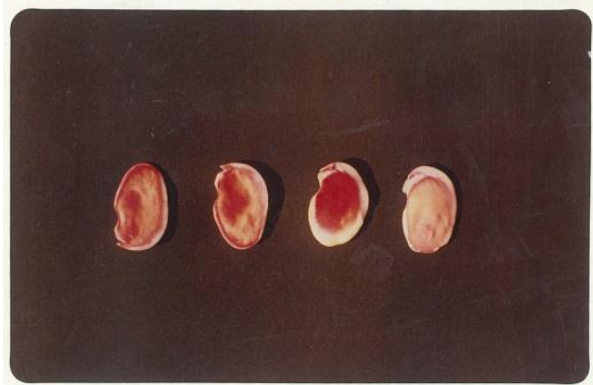

Fig : 1 \& 2 After 2,3,5 triphenyl tetrazolium Chloride staining in B. monosperma

\section{SUMMARY AND CONCLUSIONS}

In this method living cells are stained red by the reduction of a colour less tetrazolium salt to form a red formazan. The method emphasizes the need for a knowledge of the soundness of individual embryo parts for predicting the develoment of embroyos into countable seedlings.

In a comprehensive study, compared the excised embryo method with the tetrazolium method for determining the viability of dormant tree seeds. The tetrazolium method. should receive preference over the embryo excision method. improvements in the tatrazolium test should be made by providing for the use of bastericides and stronger reducing solut ions to resole doubts in weakly stained tissues.

\section{ACKNOWLEDGEMENT}

This work was supported by Prof. (Dr.) A.K. Kandya, Dr. H.S. Gour university Sagar, India.

\section{REFERENCES}

[1] Bernel, D.M. (1953-54), The use of 2,3,5 - triphenyl tetrazolium chloride for the determination of the viability of seed. Columbia, Miniteria Agri., Fiv. Invest., Infrom Tecnica, I : 79 - 129

[2] Chin, H.F. (1988) Seed storage and vigour, seed sci. \& Technol., $16: 1-4$.

[3] Dharmalingam, C. (1990) Maintenance of viability and vigour in sunflower (Helianthus annuns L.) seed. Seed Research Vol. 18(1) : $15-24,1990$. 
[4] Gupta, R.D. and Y.S. Murty (1985), Studies on seed storage and viability in some flower seeds of family Asteraceae. Seed Res., 13 (1) : 67-76.

[5] Knierim, M. and Leist. N (1988). Methodology improvement in the tetrazolium testing of viability of Abies seed. Seed Sci. and Technol. 16(1) : 227 - 237.

[6] Mckersie, B.D. and D.T. Tomes (1980) Effects of dehydration treatments on germination, seedling vigour and cytoplasmic leakage in wild oats (Avena fatua) and birds food trefoil (Lotus corniculatus) Can. J. Bot. , $58: 471-476$.

[7] Rostovtsev, S.A. and Lyubich (1978), Determination of the viability of tree and shrub seeds by staining with indigo carmine in the USSR. Seed, Sci. and Techn. $6: 869-875$.

[8] Yadav, V.K. and Khare, P.K. and Mishra, G.P. (1986). Quick test for viability and vigour in seeds of chloroxylon sweitinia J. of Trop. For., $8: 213-216$. 